\title{
The major late transcription factor binds to and activates the mouse metallothionein I promoter
}

\author{
Richard W. Carthew, ${ }^{1}$ Lewis A. Chodosh, ${ }^{1,2}$ and Phillip A. Sharp ${ }^{1}$ \\ ${ }^{1}$ Center for Cancer Research and Department of Biology, Massachusetts Institute of Technology, Cambridge, Massachusetts \\ 02139 USA; ${ }^{2}$ Harvard Medical School, Boston, Massachusetts 02115 USA
}

\begin{abstract}
Human (HeLa) cells contain a protein, MLTF, which specifically binds to a DNA sequence in the adenovirus 2 major late promoter and activates transcription of that promoter. The presence of MLTF in uninfected cells suggests that this factor contributes to the transcription of some cellular genes. We find that MLTF binds in a sequence-specific manner to the $5^{\prime}$-flanking region of the mouse metallothionein I (mMTI) gene. Binding was localized between -101 and -94 (relative to the initiation site at +1 ) by DNA-binding gel electrophoresis assay and DNA methylation interference analysis. As in adenovirus, binding occurred in a region containing the sequence CPuCGTGAC. Deletion of this sequence both eliminated the binding of MLTF and produced a fourfold reduction in transcriptional efficiency in vitro. In contrast to the intact promoter, transcription from the deletion mutant promoter was not stimulated by addition of purified MLTF to an in vitro reconstituted reaction. These results suggest that MLTF contributes to the transcription of cellular genes.
\end{abstract}

[Key Words: Transcription; adenovirus; metallothionein; promoter]

Received July 16, 1987; revised version accepted September 14, 1987.

Transcription of genes by RNA polymerase II is regulated by distinct DNA sequences or elements in the vicinity of the transcription initiation site. These sequences are recognized by protein factors that influence the rate of initiation by interacting with the transcription apparatus. One such protein factor is the adenovirus major late transcription factor (MLTF or USF), which specifically activates transcription from the adenovirus 2 major late (Ad-ML) promoter (Carthew et al. 1985; Sawadogo and Roeder 1985). As isolated from human (HeLa) cells, MLTF is a 46,000-dalton protein that binds to a site in the major late promoter with high affinity (Carthew et al. 1985; Miyamoto et al. 1985; Sawadogo and Roeder 1985; Chodosh et al. 1986).

The presence of MLTF in uninfected cells suggests that this factor is active in the transcription of cellular genes. Such genes should have MLTF-binding sites upstream of their initiation sites. A computer search of promoter sequences revealed that the $5^{\prime}$-flanking sequence of the mouse metallothionein I (mMTI) gene contains a 12-bp region exhibiting strong homology to the MLTF-binding site in the Ad-ML promoter (Glanville et al. 1981). Metallothioneins are a class of heavymetal-binding proteins important for heavy-metal detoxification and zinc homeostasis (Durnam and Palmiter 1984; Hamer 1986). Metallothioneins are usually iso- lated as two major isoforms, MTI and MTII, which are encoded by distinct genes (Hamer 1986). The metallothionein genes are transcriptionally induced by heavy metals, glucocorticoids, $\alpha$-interferon, and interleukin-1 (Durnam and Palmiter 1981; Mayo and Palmiter 1981; Hager and Palmiter 1982; Hamer and Walling 1982; Karin et al. 1984a,b; Friedman and Stark 1985). The mMTI gene is regulated in a manner similar to the other characterized metallothionein genes, and mMTI RNA can be detected in many murine tissues and cell lines in the absence of inducers (Durnam and Palmiter 1981; Mayo and Palmiter 1981).

Extensive genetic analysis of the mMTI promoter has identified sequences important for promoter function (Carter et al. 1984; Stuart et al. 1984, 1985). In addition to the four metal regulatory elements (MREs) dispersed throughout the promoter (Stuart et al. 1985), another region was identified that affects basal expression of the gene without affecting heavy-metal induction (Stuart et al. 1984). Linker scanning mutations and internal deletions localized this region to sequences between -103 and -85 , and disruption of these sequences had a fivefold effect on transcription in vivo (Stuart et al. 1984). Furthermore, a synthetic copy of the sequence -105 to -90 has been shown to confer a fivefold activation of basal expression on a $5^{\prime}$ deletion mutant of the mMTI 
promoter (P. Searle, pers. comm.). This sequence, -105 to -90 , contains the 12 -bp sequence homologous to the MLTF- binding site in adenovirus (Fig. 1).

We report here that purified MLTF binds to the sequence in the mMTI promoter and specifically stimulates transcription from the $\mathrm{mMTI}$ promoter in vitro.

\section{Results}

\section{Purified MLTF binds to the MMTI promoter}

Figure 1 shows the sequence arrangement of the various recombinant plasmids used in the present study. DNA fragments derived from these plasmids were tested for their ability to bind HeLa cell proteins using a gel electrophoresis DNA-binding assay (Fried and Crothers 1981; Garner and Revzin 1981). When a nearly homogeneous MLTF preparation (80\% purity) was incubated with an end-labeled fragment containing the complete mMTI promoter, a discrete complex of slower mobility was apparent in the DNA-binding assay (Fig. 2a). The pattern and mobility of this complex closely resembled the MLTF-DNA complex formed with Ad-ML promoter DNA. The same complex was observed when mMTI DNA was incubated with partially purified MLTF or with HeLa cell extract (Fig. 2a). Additional specific complexes that formed upon incubation of Ad-ML DNA with HeLa extract were not apparent when the same extract was incubated with mMTI DNA (Fig. 2a). The additional complexes result from binding of distinct proteins to the Ad-ML promoter (Carthew et al. 1985; L. Chodosh, unpubl.).

MLTF was specifically involved with mMTI DNA in the formation of the complex, as shown when the

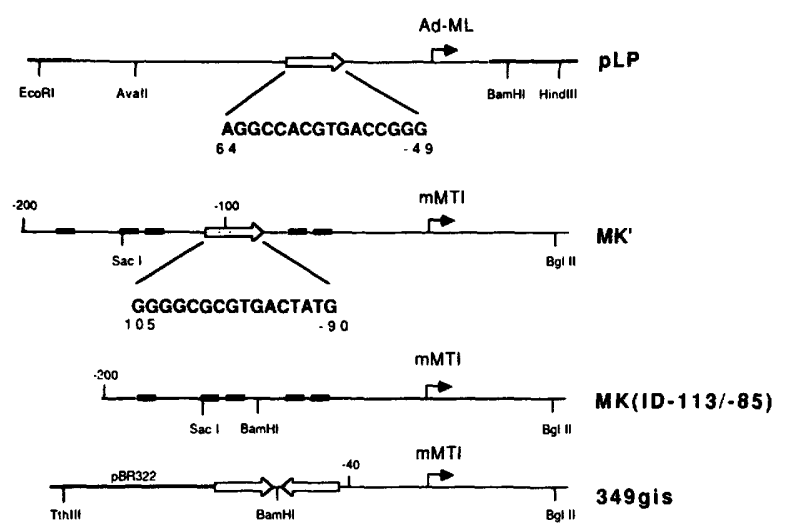

Figure 1. Sequence arrangement of mMTI and Ad-ML plasmids. Structures of the plasmid constructs pLP (Chodosh et al. 1986), pMK' (Stuart et al. 1984), pMK(ID - 113/-85) (Stuart et al. 1984), and p349gis (kindly supplied by P. Searle and R. Palmiter) were used in the binding and transcription reactions. p349gis contains two copies of mMTI sequences -105 to -90 , inserted behind the proximal $42 \mathrm{bp}$ of 5 '-flanking mMTI DNA, as described by Stuart et al. (1984). The MLTF-binding site is shown as an open arrow. Thick lines represent parental plasmid sequences; thin lines represent mammalian and viral sequences. The maps indicate the positions of the major mRNA initiation sites, with numbering relative to the initiation site at +1 . binding assay was conducted in the presence of several competitor DNAs (Fig. 2b). An unlabeled mMTI fragment competed for protein bound to the radioactive mMTI promoter DNA, as did an unlabeled fragment containing the MLTF-binding site in the Ad-ML promoter. This suggested that the same protein bound both mMTI and Ad-ML promoter DNAs. Competition was also observed using an unlabeled fragment that only included $\mathrm{mMTI}$ sequences from -105 to -90 . In contrast, a fragment of the Ad-ML promoter that did not contain the MLTF-binding site had no effect on complex formation. Moreover, no competition was observed with an unlabeled mMTI fragment bearing a deletion of sequences -113 to -85 . This deletion removes the sequences homologous to the adenovirus MLTF-binding site. Therefore, as defined by competition analysis, the mMTI sequence homologous to the Ad-ML promoter closely corresponds to the binding site for MLTF.

In the reciprocal experiment, shown in Figure $2 \mathrm{c}$, the six unlabeled fragments were added to a binding reaction containing labeled Ad-ML promoter DNA. All of the fragments that contained a potential MLTF-binding site competed with the labeled Ad-ML DNA for MLTF (Fig. $2 \mathrm{cl}$. Fragments that lacked the potential binding site did not abolish formation of the complex on the radioactive Ad-ML DNA. Therefore, by competition analysis, MLTF binds to the mMTI promoter at a site that corresponds closely to the MLTF homology. The relative affinity of MLTF for the mMTI promoter was approximately the same as that for the Ad-ML promoter, as determined by titrations of competitor DNAs (data not shown). Interestingly, when the binding reactions were performed in the presence of $5 \mathrm{mM} \mathrm{MgCl}_{2}$, the relative affinity of MLTF for the mMTI promoter was fivefold lower than that for Ad-ML promoter (data not shown). A similar observation has been made with MLTF binding to the rat $\gamma$-fibrinogen promoter (Chodosh et al. 1987). Because the association equilibrium constant for MLTF binding to the Ad-ML site was previously estimated to be approximately $10^{10} \mathrm{M}^{-1}$ (Chodosh et al. 1986), the affinity for MLTF interaction with the mMTI promoter is likely within an order of magnitude of this value.

\section{Methylation interference patterns of $M L T F-D N A$ complexes}

DNA methylation interference experiments were carried out to define further the MLTF-binding site in the mMTI promoter. Labeled mMTI DNA was partially methylated with dimethylsulfate (DMS), which attaches a methyl group to the $\mathrm{N}-7$ position of individual guanines (Maxam and Gilbert 1980). The DNA was incubated with partially purified MLTF, and the proteinDNA complexes were resolved by gel electrophoresis. DNA from the complexes and unbound DNA were recovered, cleaved with piperidine, and electrophoresed on a denaturing polyacrylamide gel. Fragments containing methylated guanines that interfere with protein binding should not be present in DNA recovered from the complexes. Comparison of the cleavage pattern of bound and unbound DNA revealed that the binding site of the 

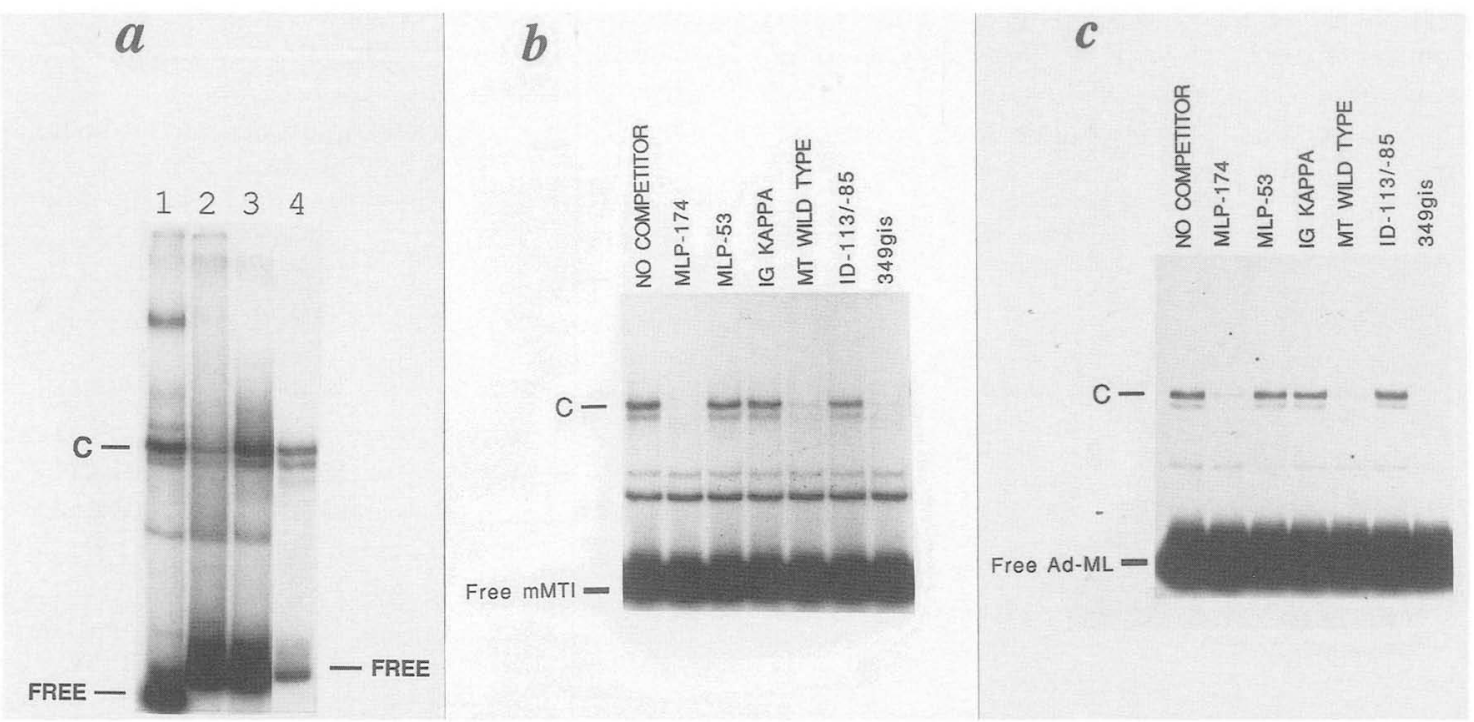

Figure 2. (a) Binding of DNA fragments with different preparations of MLTF. Labeled DNA containing the Ad-ML promoter (lane 1) or the mMTI promoter (lanes 2-4) was incubated with carrier DNA and either $8 \mu \mathrm{g} \mathrm{HeLa}$ whole-cell extract protein (lanes 1 and 2), 40 $\mu \mathrm{g}$ of a DEAE-Sephacel flow-through protein fraction containing MLTF (Carthew et al. 1985) (lane 3), or $90 \mathrm{pg}$ (2 fmole) of affinity-purified MLTF monomer (Chodosh et al. 1986) (lane 4). The labeled mMTI DNA fragment was derived from a BgIII-SacI digest of pMK' and was labeled at the BgIII end. The labeled Ad-ML DNA fragment was derived from an EcoRI-HindIII digest of pLP. The reaction with purified MLTF monomer did not contain carrier DNA. Protein-DNA complexes and unbound DNA were resolved in a polyacrylamide gel. The predominant protein-DNA complex visualized is labeled C. $(b)$ Binding of MLTF to mMTI in the presence of competitor DNA. The labeled mMTI DNA fragment (4 fmole) was incubated with a 240 -fmole competitor fragment, as indicated above each lane, and $4 \mu 1$ of a DEAE-Sephacel flow-through fraction containing MLTF. The products were resolved in a polyacrylamide gel. Bands that are not labeled $\mathrm{C}$ and that electrophorese more slowly than the free DNA are due to nonspecific complexes with HeLa proteins (data not shown). Six competitor fragments were prepared: (MLP-174) a 256-bp fragment extending from -174 to +33 of the Ad-ML promoter (Chodosh et al. 1986); (MLP-53) a 133-bp fragment extending from -53 to +33 of the Ad-ML promoter (Chodosh et al. 1986); (Ig-k) a 350-bp fragment including the MOPC-41 $\mathrm{\kappa}$-immunoglobulin promoter (Singh et al. 1986); (MT wild type) a 219-bp fragment derived from a BglII-Sacl digest of plasmid pMK'; (ID-113/-85) a 201-bp fragment derived from Bg/II-SacI digest of plasmid pMK(ID-113/-85); (349gis) a 178-bp fragment derived from a TthIII-BamHI digest of plasmid p349gis. (c) Binding of MLTF to Ad-ML promoter in the presence of competitor DNA. Incubation conditions and competitor fragments used are as in $b$.

factor in the mMTI promoter was region 5'CGCGTGAC-3' (-101 to -94) (Fig. 3a). This sequence is part of the dodecanucleotide that is highly homologous to the MLTF-binding site in adenovirus. The analogous methylation interference experiment was carried out with a labeled DNA fragment containing the Ad-ML promoter (Fig. 3b). The binding site of MLTF, as delineated by methylation interference, was in the region $5^{\prime}$ CACGTGAC-3' $(-60$ to -53$)$ which lies within the DNase I footprint of MLTF (Carthew et al. 1985; Miyamoto et al. 1985; Sawadogo and Roeder 1985). The nucleotide sequence is almost identical in the Ad-ML- and mMTI-binding regions. Moreover, close contacts between MLTF and the major groove of the DNA helix, as delineated by the methylation interference pattern, followed a common spatial arrangement (Fig. 3c). The quantitative effect of methylation at each of these positions was also similar for the two complexes. However, an additional close contact with the guanine at position -100 on the mMTI-coding strand was detected by methylation interference. The equivalent position in the Ad-ML promoter is not occupied by a guanine residue but an adenine residue. This suggests that MLTF does not interact with unique features of the base pair at this position but does make close contact in the major groove at this position. Interestingly, the sequence of the MLTF-binding sites in both promoters has imperfect dyad symmetry, and yet the arrangement of positions where methylation of guanine residues interferes with binding is asymmetric with respect to the palindrome. This degree of asymmetry in the pattern of close contacts with guanine residues has not been observed with prokaryotic proteins that bind as oligomers and recognize palindromic sequences (Johnson et al. 1978; Pabo and Sauer 1984). It was previously observed that purified MLTF exists in solution in monomeric form /Chodosh et al. 1986). Possibly, MLTF binds DNA as a monomer and recognizes its symmetric cognate sequence in an asymmetric manner.

\section{MLTF activates mMTI transcription in vitro}

Mutational analysis has shown that sequences bearing the MLTF-binding site between -105 and -90 of the mMTI promoter contribute fivefold to the basal level of transcription in vitro (Stuart et al. 1984). It was therefore important to show that purified MLTF could stimulate transcription in vitro from the mMTI promoter in a manner that was dependent upon recognition of these same sequences. Transcription of the mMTI gene in 

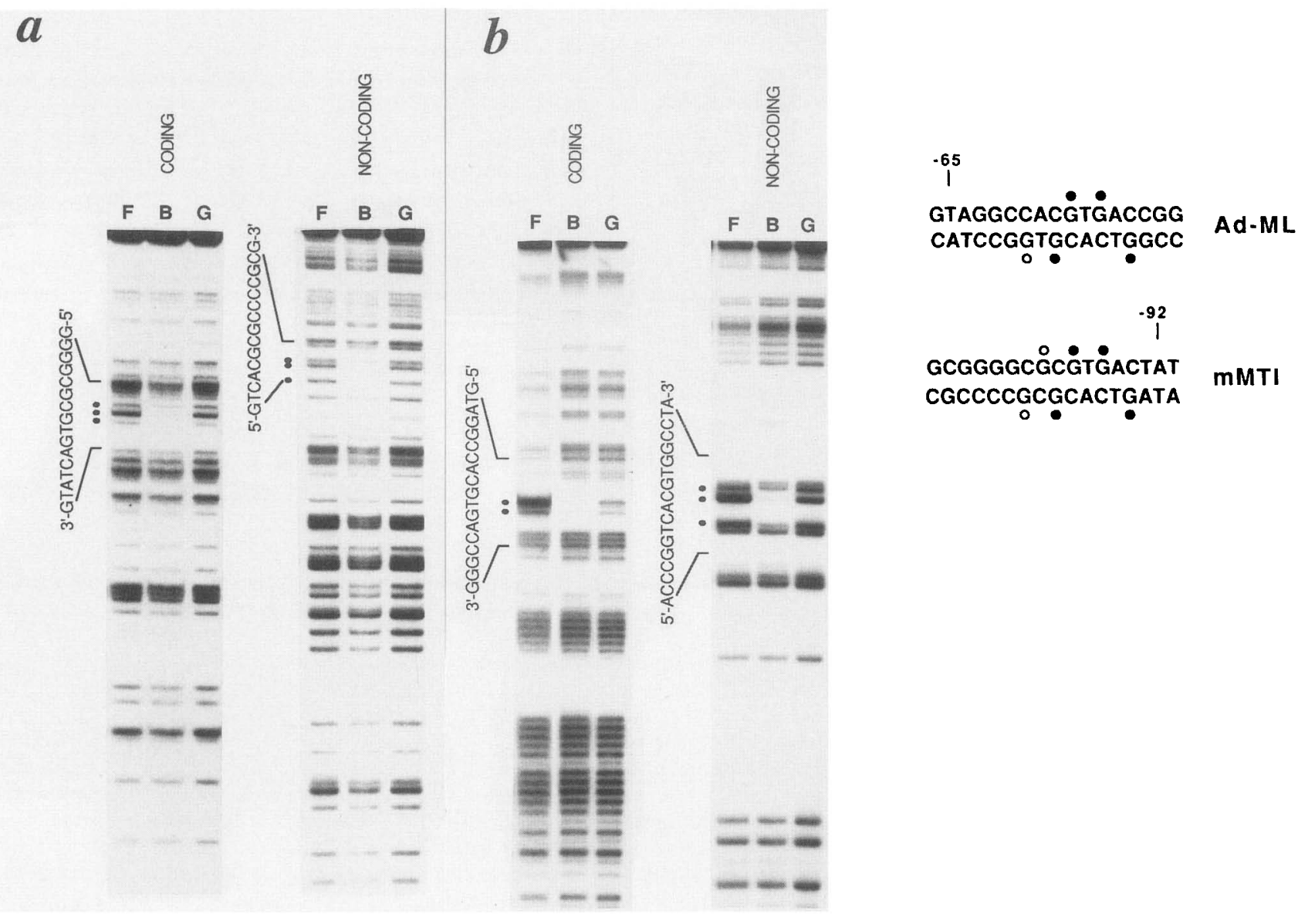

Figure 3. Methylation interference analysis of MLTF binding to mMTI and Ad-ML DNAs. $\{a \mid$ Binding to the mMTI promoter. The coding strand was $3^{\prime}$-end-labeled with the large fragment of $E$. coli DNA polymerase I and the noncoding strand was $5^{\prime}$ end-labeled with $\left[\gamma^{-32}\right.$ P]ATP and T4 polynucleotide kinase at the BglII site of pMK' located downstream from the initiation site. (F, B) DNAs recovered from the free and specifically bound species, which were produced during the binding reaction and resolved in a polyacrylamide gel; $(G)$ a chemical cleavage ladder at $G$ residues in the labeled DNA. $(b)$ Binding to the Ad-ML promoter. The coding strand was $3^{\prime}$-end-labeled, and the noncoding strand was 5 '-end-labeled at the BamHI site of plasmid pLP. The plasmid was recut with AvaII, and the 177-bp fragment was isolated. (F, B, and $G$ are described above.) (c) Close contact points between MLTF and the mMTI or the Ad-ML sequences. The sequences of $\mathrm{mMTI}$ and Ad-ML DNA containing the MLTF-binding regions are displayed. Contacted guanine residues identified by methylation interference are marked by closed circles for strongly interfering residues and by open circles for weakly interfering residues. The sequence palindrome in the Ad-ML promoter is centered between positions -57 and -58 , and extends on one side to -63 and on the other side to -52 . The sequence palindrome in the mMTI promoter is centered between -98 and -99 , and extends on one side to -103 and on the other side to -94 .

vitro with a HeLa whole-cell extract was assayed by $\mathrm{S} 1$ nuclease analysis (Fig. 4a). RNA synthesized from this promoter initiated accurately at positions used by in vivo (Glanville et al. 1981). A promoter with an internal deletion from -113 to -85 , which deletes the MLTFbinding site (ID-113/-85), was transcribed fourfold less efficiently than wild type (Fig. 4a). This mutant promoter is about fivefold less active than wild type in vivo (Stuart et al. 1984). In addition, a mMTI promoter construct was tested in which two copies of the MLTFbinding site from -105 to -90 had been inserted as an inverted repeat behind position -42 of a truncated mMTI promoter (see Fig. 1). This promoter is as active as the uninduced wild-type promoter in vivo (P. Searle, pers. comm.). In vitro, this promoter construct (349gis) was transcribed at a level twofold higher than wild type
(Fig. 4a). Thus, sequences containing the MLTF-binding site contribute to the transcription activity of the mMTI gene in a HeLa extract.

The S1 nuclease assays also showed evidence of RNAs that were significantly longer than those generated at the mMTI initiation site. Production of these RNAs also appeared dependent on the presence of the MLTFbinding site and addition of MLTF. Because circular DNA templates were used in the transcription reactions, RNAs generated by multiple rounds of transcription of the template would have been detected by S1 nuclease analysis as RNAs with the length observed in Figure 4. Thus, the longer RNAs detected in the above experiments probably were generated by initiation at the mMTI site.

To test whether the dependence of mMTI transcrip- 
tion activity on sequences between -85 and -113 was due to promoter activation by MLTF, transcription in vitro was performed with a partially purified transcription system (Samuels et al. 1982), where MLTF had been separated from the general transcription factors by column chromatography (Carthew et al. 1985). In contrast to the results obtained using HeLa extract, all of the mMTI promoters were equally active in the general reconstituted transcription system (Fig. 4b). Addition of partially purified MLTF to the general transcription system produced a threefold activation in transcription from the wild-type mMTI promoter (Fig. 4b). The mutant mMTI promoter ID $-113 /-85$, which had been shown to be unable to bind MLTF, was not transcriptionally stimulated by addition of MLTF. Moreover, the mMTI promoter 349gis, with two copies of the MLTFbinding site inserted behind the minimal promoter, gave a fivefold stimulation of transcription when MLTF was added to the reaction. Even though the MLTF- binding site had been duplicated and moved $54 \mathrm{bp}$ closer to the mMTI initiation site, there was only a minor effect on the ability of the promoter to be transcriptionally stimulated by MLTF. These results indicate that MLTF binds specifically to the mMTI promoter, and this specific protein-DNA interaction contributes directly to promoter strength in vitro.

\section{Discussion}

We have demonstrated that a promoter-specific transcription factor from HeLa cells that is involved in adenovirus gene transcription is also involved in the transcription of cellular genes. This factor MLTF likely activates transcription of a cellular gene, the mMTI gene, through sequence-specific binding to its promoter. This proposed mechanism in which MLTF activates transcription by binding to a promoter was originally suggested by the close correlation between the sequencespecific DNA-binding and transcription activities of MLTF on the Ad-ML promoter (Carthew et al. 1985; Sawadogo and Roeder 1985; Chodosh et al. 1986) and by the finding that a single polypeptide possesses both of these activities (Chodosh et al. 1986). Other transcription factors that possess sequence specific DNA-binding activities are also involved in the transcription of both cellular and viral genes (Dynan et al. 1986; Jones et al. 1986; Morgan et al. 1987). Thus, it appears to be a common strategy for animal viruses to utilize host promoter-specific transcription factors for viral gene expression.

Several lines of evidence support the contention that the mMTI promoter element $(-101$ to -94$)$ interacts with MLTF. First, this sequence is highly homologous to the MLTF-binding site in the Ad-ML promoter/Carthew

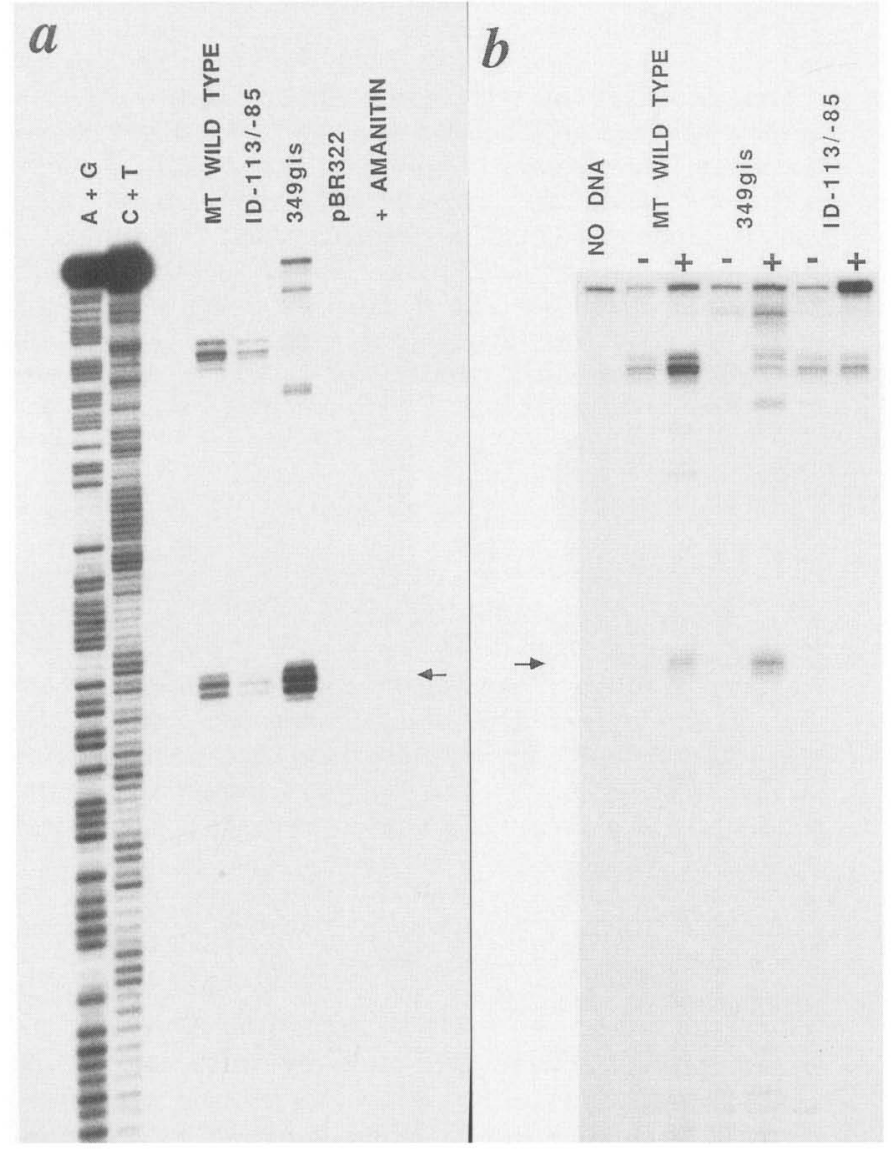

Figure 4. S1 nuclease analysis of RNA synthesized in vitro from the mMTI promoter. (a) Transcription reactions with HeLa whole-cell extract. Reactions contained $6 \mu 1$ of HeLa whole-cell extract and $200 \mathrm{ng}$ of supercoiled DNA template, as indicated above each lane. (MT wild-type) Contained $\mathrm{pMK}^{\prime}$ as template; (ID $-113 /-85$ ) contained $\mathrm{pMK}(\mathrm{ID}-113 /-85$ ) as template; (amanitin) contained $\mathrm{pMK}^{\prime}$ as template and $0.5 \mu \mathrm{g} / \mathrm{ml} \alpha$-amanitin. (A + G) A chemical cleavage ladder of $A$ and $G$ residues in the probe DNA; $(C+T)$ a chemical cleavage ladder of $C$ and T residues in the probe DNA. $\rightarrow$ Transcripts initiating at the expected position. $|b|$ MLTF-dependent in vitro transcription. All reactions contained a mixture of RNA polymerase II and fractionated general RNA polymerase II transcription factors prepared from HeLa whole-cell extract, as described previously (Samuels et al. 1982). The DNA template used in each reaction is indicated above each lane. (MT wild-type) Contained pMK' as template. (Lanes - and +) Reactions that contained 0 or $3 \mu l$ of MLTF, respectively. $(\rightarrow)$ Transcripts initiating at the expected position. 
et al. 1985; Miyamoto et al. 1985; Sawadogo and Roeder 1985). Second, a nearly homogeneous MLTF preparation ( $80 \%$ purity) binds with high affinity to this sequence in the mMTI promoter. Third, this sequence effectively competes with Ad-ML DNA for binding of MLTF. Finally, the pattern of close contacts of MLTF on Ad-ML and mMTI DNA, as mapped by methylation interference, is located over homologous regions. The MLTFbinding site in the mMTI promoter contributes to the basal transcriptional efficiency of the promoter both in vivo and in vitro (Stuart et al. 1984; Fig. 4a). Moreover, transcription from the mMTI promoter was stimulated by the addition of MLTF to a partially purified transcription system only if the promoter contained the MLTF site. Stimulation of transcription by MLTF was not highly dependent upon the exact position of the MLTF site, with respect to the MMTI TATA box or initiation site.

A search through the other cloned mammalian metallothionein genes failed to reveal other potential MLTFbinding sites, even though other transcriptional elements are highly conserved among these genes (Carter et al. 1984; Karin et al. 1984; Searle et al. 1984; Stuart et al. 1984). Basal activity of the human MT-IIA promoter is controlled instead by two copies of a transcriptional enhancer, which interact with distinct transcription factors (Lee et al. 1987). Possibly, the basal expression of individual metallothionein genes is controlled by the number and strength of different promoter elements such as the MLTF element, which thereby tailors expression to fit specialized functions of the different genes. Surprisingly, the metallothionein gene of Neurospora crassa contains a potential MLTF-binding site in its promoter region, though it is unclear yet if this sequence plays a role in metallothionein expression (Munger et al. 1985).

Although the mMTI gene is active when transfected into HeLa cells (Mayo et al. 1982), it was important to establish that MLTF is present in murine cells. MLTF activity was detected in extracts made from a wide variety of mouse cell lines, including a Friend erythroleukemia cell line, an EC-F9 cell line, a WEHI B cell line, and a BALB/C-3T3 cell line $(R$. Carthew, L. Chodosh, and A. Baldwin, unpubl.). The correlation between the near ubiquitous expression of the mMTI gene in murine tissues (Durnam and Palmiter 1981; Mayo and Palmiter 1981) and the apparent presence of MLTF in many of these same tissues is consistent with MLTF having a functional role in mMTI expression. Interestingly, there is no detectable transcription of the mMTI gene in murine lymphocytes (Durnam and Palmiter 1981; Mayo and Palmiter 1981\}, even though levels of MLTF in extracts from lymphocytes are comparable to levels in extracts from cells that express mMTI. Possibly, other determinants such as chromatin structure prevent MLTF from interacting with the mMTI promoter in these cells, or a cell-type transcriptional element represses transcription of the gene.

A search for other potential MLTF-binding sites in the 5 '-flanking regions of mammalian genes has turned up several candidates. Genes with potential binding sites include the rat and human growth hormone genes (Barta et al. 1981; Denoto et al. 1981), the rat $\beta$ - and $\gamma$-fibrinogen genes (Fowlkes et al. 1984), the human $\epsilon$-globin gene (Baralle et al. 1980), and the human kininogen gene (Kitamura et al. 1986). It has recently been shown that the $\gamma$-fibrinogen promoter binds MLTF and is transcriptionally stimulated by MLTF in vitro (Chodosh et al. 1987). There is no common pattern of regulation for this diverse group of genes. Thus, it remains unclear whether MLTF binding to promoters merely functions to maintain constitutive promoter strength or functions to regulate promoter activity through complex combinational interactions with other transcription factors.

\section{Materials and methods}

\section{Plasmids}

The plasmid pLP contains 206 bp of Ad-ML promoter DNA $1-174$ to +33 relative to the start site inserted in pUC13 (Chodosh et al. 1986). The mMTI plasmids pMK' (Stuart et al. 1984), pMK (ID-113/-85) (Stuart et al. 1984), and p349gis were kindly supplied by P. Searle and R. Palmiter. p349gis contains two copies of $\mathrm{mMTI}$ sequences, -105 to -90 , inserted behind the proximal $42 \mathrm{bp}$ of $5^{\prime}$-flanking mMTI DNA, as described by Stuart et al. (1985).

\section{DNA-binding reactions}

DNA fragments were isolated and labeled with [ $\left.\alpha-{ }^{-32} \mathrm{P}\right] \mathrm{dATP}$ and the large fragment of Escherichia coli DNA polymerase, as described previously (Carthew et al. 1985). Whole-cell extract from HeLa cells (Manley et al. 1980) was fractionated as described (Samuels et al. 1982), and MLTF was purified to homogeneity as described (Chodosh et al. 1986). Binding reactions contained 2-4 fmoles of labeled DNA and, if necessary, $2 \mu \mathrm{g}$ poly $(\mathrm{dI}-\mathrm{dC}) \cdot(\mathrm{dI}-\mathrm{dC})$ as carrier DNA. Binding reactions $(10 \mu \mathrm{l})$ were performed in $12 \mathrm{~mm}$ HEPES NaOH $(\mathrm{pH} 7.9), 60 \mathrm{~mm} \mathrm{KCl}$, $0.6 \mathrm{~mm}$ dithiothreitol (DTT), $1 \mathrm{mM}$ EDTA, and $12 \%$ glycerol. After incubation at $30^{\circ} \mathrm{C}$ for $15 \mathrm{~min}$, the complexes were resolved in a nondenaturing $4 \%$ polyacrylamide gel, as described previously (Carthew et al. 1985).

\section{Methylation interference analysis}

The labeled DNA ( 25 fmoles; $10^{5} \mathrm{cpm}$ ) was methylated with DMS for $5 \mathrm{~min}$ at $20^{\circ} \mathrm{C}$. After two ethanol precipitations, the DNA was incubated with $40 \mu \mathrm{g}$ of the DEAE-Sephacel flowthrough fraction protein in a binding reaction scaled up 10-fold from the analytical reactions. The products were electrophoresed in a $4 \%$ polyacrylamide gel and, after autoradiography to visualize the DNA, the DNA was eluted from the regions of the gel containing the free DNA and protein-DNA complexes (Baldwin and Sharp 1987). The DNA was cleaved with $1 \mathrm{M}$ piperidine in $100 \mu \mathrm{l}$ at $90^{\circ} \mathrm{C}$ for $30 \mathrm{~min}$. A portion of the original methylated DNA was also piperidine-treated to serve as a marker ladder. After lyophilization, the products were electrophoresed in an $8 \%$ polyacrylamide $-8 \mathrm{M}$ urea sequencing gel and were visualized by autoradiography.

\section{Transcription reactions}

Reactions with HeLa whole-cell extract (Manley et al. 1980) contained $6 \mu \mathrm{l}$ of extract and $200 \mathrm{ng}$ of supercoiled DNA tem- 
plate in a total volume of $10 \mu \mathrm{l}$. Reactions were performed as described elsewhere (Carthew et al. 1985) except that reactions also contained $10 \mathrm{~mm}$ ammonium sulfate and $200 \mu \mathrm{m}$ of each nucleoside triphosphate. RNA derived from reactions was analyzed by S1 nuclease analysis (Berk and Sharp 1977). All reactions were stopped by addition of $1 \mu \mathrm{g} / \mathrm{ml} \alpha$-amanitin, and template DNA was digested with 1 unit DNase I (Promega) at $30^{\circ} \mathrm{C}$ for $10 \mathrm{~min}$. RNA was extracted with phenol : chloroform : isoamyl alcohol followed by a chloroform extraction. RNA was then coprecipitated in ethanol with 50 fmoles $(300,000 \mathrm{cpm})$ of radioactive probe DNA. RNA was hybridized to the probe DNA for $3 \mathrm{hr}$ at $45^{\circ} \mathrm{C}$ in $10 \mu \mathrm{l}$ of $80 \%$ formamide, $400 \mathrm{mM} \mathrm{NaCl}, 50$ mM PIPES (pH 6.4), and 1 mM EDTA; it was subsequently digested with 1200 units S1 nuclease (Boehringer-Mannheim) at $16^{\circ} \mathrm{C}$ for $60 \mathrm{~min}$ in $400 \mu \mathrm{lmM}$ sodium acetate (pH 4.5), $4 \mathrm{~mm}$ $\mathrm{ZnSO}_{4}, 280 \mathrm{mM} \mathrm{NaCl}, 10 \mu \mathrm{g} / \mathrm{ml}$ denatured calf thymus DNA, and $5 \%$ glycerol. Digestions were stopped with $10 \mathrm{mM}$ EDTA and $20 \mu \mathrm{g}$ tRNA, and the nuclease-resistant products were ethanol-precipitated and electrophoresed in an $8 \%$ polyacrylamide- $8 \mathrm{M}$ urea sequencing gel. In all analyses, probe DNA was a BglII-BamHI fragment derived from plasmid p349gis, which was end-labeled with T4 polynucleotide kinase and $\left[\gamma^{32} \mathrm{P}\right] \mathrm{ATP}$ at the $B g / I I$ site.

Transcription reactions involving the addition of MLTF to the reaction were performed using a mixture of purified RNA polymerase II and fractionated general RNA polymerase II transcription factors prepared from HeLa whole-cell extract, as described previously (Samuels et al. 1982). Final reaction volumes were $20 \mu \mathrm{l}$, including $100 \mathrm{ng}$ of supercoiled DNA template, 100 ng of carrier DNA, and a mixture of chromatographic fractions, as indicated necessary for MLTF activation of the Ad-ML promoter (Carthew et al. 1985). Reaction conditions were as described (Carthew et al. 1985), except that reactions also contained $10 \mathrm{~mm}$ ammoniom sulfate but did not contain $\mathrm{MgCl}_{2}$ or nucleoside triphosphates. After incubation at $30^{\circ} \mathrm{C}$ for $60 \mathrm{~min}$, nucleoside triphosphates and $\mathrm{MgCl}_{2}$ were added to final concentrations of $60 \mu \mathrm{M}$ and $5 \mathrm{mM}$, respectively, and the reaction proceeded for an additional $30 \mathrm{~min}$ at $30^{\circ} \mathrm{C}$. RNA was prepared and analyzed as described above.

\section{Acknowledgments}

We thank Richard Palmiter and Peter Searle for providing the mMTI plasmids; Richard Palmiter, Peter Searle, Albert Baldwin, and Angus Lamond for helpful comments on the manuscript; and Margarita Siafaca for typing the manuscript. We thank Bob Marciniak for help on use of his homologysearch program Fitconsensus. L.A.C. is supported by the Harvard Medical School M.D./Ph.D. Program and the Massachusetts Institute of Technology Department of Biology. This work was supported by U.S. Public Health Service grant PO1CA42063 from the National Institutes of Health, grant CDR-8500003 from the National Science Foundation and, partially, by National Cancer Institute Cancer Center core grant P30-CA14051 to P.A.S.

\section{References}

Baldwin, A.S., Jr. and P.A. Sharp. 1987. Binding of a nuclear factor to a regulatory sequence in the promoter of the mouse $\mathrm{H} 2 \mathrm{~K}^{\text {b }}$ class I major histocompatibility gene. Mol. Cell. Biol. 7: 305-313.

Baralle, F.E., C.E. Shoulders, and N.J. Proudfoot. 1980. The primary structure of the human epsilon-globin gene. Cell 21: $621-626$.

Barta, A., R.I. Richards, J.D. Baxter, and J. Shine. 1981. Primary structure and evolution of rat growth hormone gene. Proc. Natl. Acad. Sci. 78: 4867-4871.

Berk, A.J. and P.A. Sharp. 1977. Sizing and mapping of early adenovirus mRNAs by gel electrophoresis of S1 endonuclease digested hybrids. Cell 12: 721-732.

Carter, A.D., B.K. Felber, M.J. Walling, M.-F. Jubier, C.J. Schmidt, and D.H. Hamer. 1984. Duplicated heavy metal control sequences of the mouse metallothionein-I gene. Proc. Natl. Acad. Sci. 81: 7392-7396.

Carthew, R.W., L.A. Chodosh, and P.A. Sharp. 1985. An RNA polymerase II transcription factor binds to an upstream element in the adenovirus major late promoter. Cell 43: 439448.

Chodosh, L.A., R.W. Carthew, and P.A. Sharp. 1986. A single polypeptide possesses the binding and transcription activities of the major late transcription factor of adenovirus. Mol. Cell. Biol. 6: 4723-4733.

Chodosh, L.A., R.W. Carthew, J.G. Morgan, G.R. Crabtree, and P.A. Sharp. 1987. The adenovirus major late transcription factor activates the rat $\gamma$-fibrinogen promoter. Science (in press).

Denoto, F.M., D.D. Moore, and H.M. Goodman. 1981. Human growth hormone sequence and mRNA structure: Possible alternative splicing. Nucleic Acids Res. 9: 3719-3930.

Durnam, D.M. and R.D. Palmiter. 1981. Transcriptional regulation of the mouse metallothionein-I gene by heavy metals. $J$. Biol. Chem. 256: 5712-5716.

-1984. Induction of metallothionein-I mRNA in cultured cells by heavy metals and iodoacetate: Evidence for gratuitous inducers. Mol. Cell. Biol. 4: 484-491.

Dynan, W.S., S. Sazer, R. Tjian, and R.T. Schimke. 1986. Transcription factor SP1 recognizes a DNA sequence in the mouse dihydrofolate reductase promoter. Nature 319: 246249.

Fowlkes, D.M., N.T. Mullis, C.M. Comeau, and G.R. Crabtree. 1984. Potential basis for regulation of the coordinately expressed fibrinogen genes: Homology in the $5^{\prime}$-flanking regions. Proc. Natl. Acad. Sci. 81: 2313-2316.

Fried, M. and D.M. Crothers. 1981. Equilibria and kinetics of lac repressor-operator interactions by polyacrylamide gel electrophoresis. Nucleic Acids Res. 9: 6505-6525.

Friedman, R.L. and G.R. Stark. 1985. $\alpha$-Interferon induced transcription of HLA and metallothionein genes containing homologous upstream sequences. Nature 314: 637-639.

Garner, M.M. and A. Revzin. 1981. A gel electrophoresis method for quantifying the binding of proteins to specific DNA regions. Applications to components of the E. coli lactose operon regulatory system. Nucleic Acids Res. 9: 30473058.

Glanville, N., D.M. Durnam, and R.D. Palmiter. 1981. Structure of mouse metallothionein I gene and its mRNA. Nature 292: $267-269$.

Hager, L.J. and R.D. Palmiter. 1982. Transcriptional regulation of mouse liver metallothionein I gene by glucocorticoid. Nature 291: 340-342.

Hamer, D.H. 1986. Metallothionein. Annu. Rev. Biochem. 55: 913-952.

Hamer, D.H. and M. Walling. 1982. Regulation in vivo of a cloned mammalian gene: Cadmium induces the transcription of a mouse metallothionein gene in SV40 vectors. $J$. Mol. Appl. Genet. 1: 273-288.

Johnson, A.D., B.J. Meyer, and M. Ptashne. 1978. Mechanism of action of the cro protein of bacteriophage $\lambda$. Proc. Natl. Acad. Sci. 75: 1783-1787.

Jones, K.A., J.T. Kadonaga, P.A. Luciw, and R.T. Tjian. 1986. Activation of the AIDS retrovirus promoter by the cellular transcription factor, SP1. Science 232: 755-759. 
Karin, M., R.J. Imbra, A. Heguy, and G. Wong. 1985. Interleukin I regulates human metallothionein gene expression. Mol. Cell. Biol. 5: 2866-2869.

Karin, M., A. Haslinger, H. Holtgreve, G. Cathala, E. Slater, and J.D. Baxter. 1984a. Activation of a heterologous promoter in response to dexamethasone and cadmium by metallothionein gene 5'-flanking DNA. Cell 36: 371-379.

Karin, M., A. Haslinger, H. Holtgreve, R.I. Richards, P. Krauter, H.M. Westphal, and M. Beato. 1984b. Characterization of DNA sequences through which cadmium and glucocorticoid hormones induce human metallothionein-IIA gene. Nature 308: 513-519.

Kitamura, N., H. Kitagawa, D. Fukushima, Y. Takagaki, T. Miyata, T. Nakanishi, and S. Nakanishi. 1986. Structure organization of the human kininogen gene and a model for its evolution. J. Biol. Chem. 260: 8610-8620.

Lee, W., A. Haslinger, M. Karin, and R. Tjian. 1987. Activation of transcription by two factors that bind promoter and enhancer sequences of the human metallothionein gene and SV40. Nature 325: 368-372.

Manley, J.L., A. Fire, A. Cano, P.A. Sharp, and M.L. Gefter. 1980. DNA- dependent transcription of adenovirus genes in a soluble whole-cell extract. Proc. Natl. Acad. Sci. 77: 3855-3859.

Mayo, K.E. and R.D. Palmiter. 1981. Glucocorticoid regulation of metallothionein-I mRNA synthesis in cultured mouse cells. J. Biol. Chem. 256: 2621-2624.

Mayo, K.E., R. Warren, and R.D. Palmiter. 1982. The mouse metallothionein-I gene is transcriptionally regulated by cadmium following transfection into human or mouse cells. Cell 29: 99-108.

Maxam, A. and W. Gilbert. 1980. Sequencing end-labeled DNA with base- specific chemical cleavages. Methods Enzymol. 65: 499-560.

Miyamoto, N.G., V. Moncollin, J.M. Egly, and P. Chambon. 1985. Specific interaction between a transcription factor and the upstream element of the adenovirus- 2 major late promoter. EMBO J. 4: 3563-3570.

Morgan, W.D., G.T. Williams, R.I. Morimoto, J. Green, R.E. Kingston, and R. Tjian. 1987. Two transcriptional activators, CCAAT-box-binding transcription factor and heat shock transcription factor, interact with a human hsp 70 gene promoter. Mol. Cell. Biol. 7: 1129-1138.

Munger, K., U.A. Germann, and K. Lerch. 1985. Isolation and structural organization of the Neurospora crassa copper metallothionein gene. EMBO I. 4: 2665-2668.

Pabo, C.O. and R.T. Sauer. 1984. Protein-DNA recognition. Annu. Rev. Biochem. 53: 293-321.

Samuels, M., A. Fire, and P.A. Sharp. 1982. Separation and characterization of factors mediating accurate transcription by RNA polymerase II. J. Biol. Chem. 257: 14419-14427.

Sawadogo, M. and R.G. Roeder. 1985. Interaction of a gene-specific transcription factor with the adenovirus major late promoter upstream of the TATA box region. Cell 43: 165-175.

Searle, P.F., B.L. Davison, G.W. Stuart, T.M. Wilkie, G. Norstedt, and R.D. Palmiter. 1984. Regulation, linkage, and sequence of mouse metallothionein I and II genes. Mol. Cell. Biol. 4: 1221-1230.

Singh, H., R. Sen, D. Baltimore, and P.A. Sharp. 1986. A nuclear factor that binds to a conserved sequence motif in transcriptional control elements of immunoglobulin genes. Nature 319: $154-158$.

Stuart, G.W., P.F. Searle, and R.D. Palmiter. 1985. Identification of multiple metal regulatory elements in mouse metallothionein-I promoter by assaying synthetic sequences. $\mathrm{Na}$ ture 317: 828-831.
Stuart, G.W., P.F. Searle, H.Y. Chen, R.L. Brinster, and R.D. Palmiter. 1984. A 12-base-paor DNA motif that is repeated several times in metallothionein gene promtoers confers metal regulation to a heterologous gene. Proc. Nat1. Acad. Sci. 81: 7318-7322. 


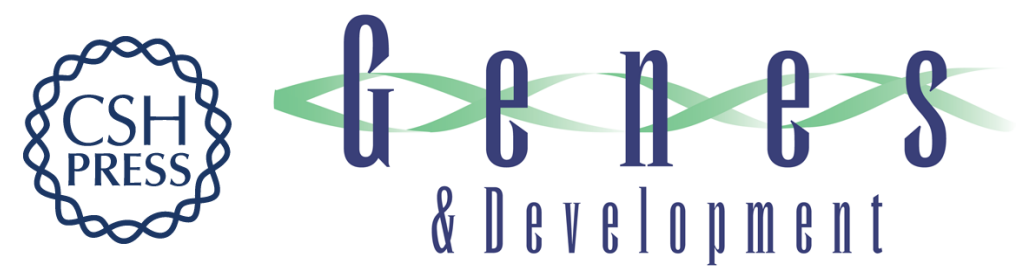

\section{The major late transcription factor binds to and activates the mouse metallothionein I promoter.}

R W Carthew, L A Chodosh and P A Sharp

Genes Dev. 1987, 1:

Access the most recent version at doi:10.1101/gad.1.9.973

$\begin{array}{ll}\text { References } & \text { This article cites } 40 \text { articles, } 16 \text { of which can be accessed free at: } \\ \text { http://genesdev.cshlp.org/content/1/9/973.full.html\#ref-list-1 }\end{array}$

License

Email Alerting Receive free email alerts when new articles cite this article - sign up in the box at the top Service right corner of the article or click here.

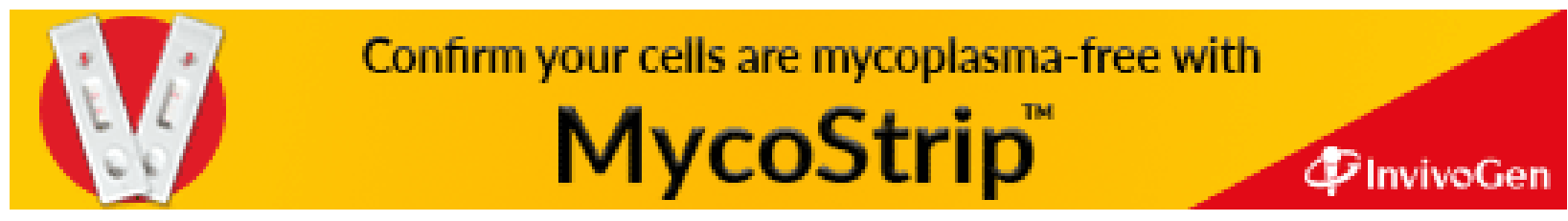

